UDC 576.5: 577.2:636.597.8:

\title{
Generation of transgenic ducks by crispr/CAS9-mediated gene inser- tion combined with the sperm-mediated gene transfer (SMGT)
}

\author{
O. Konoval ${ }^{1,3}$, P. Korol ${ }^{5}$, P. Tabaka ${ }^{1}$, S. Kostenko ${ }^{4}$, L. Lizhi ${ }^{1}$, A. Chepiha ${ }^{4}$,
} M. Doroshenko ${ }^{4}$, M. Drahulian 4 , B. Xingchen ${ }^{1}$, H. Xuetao ${ }^{2}$, L. Liumeng ${ }^{2}$

${ }^{1}$ Institute of Animal Husbandry and Veterinary Science, Zhejiang Academy of Agricultural Sciences 198 Shiqiao Road, 310021, Hangzhou, Zhejiang, China;

2 Zhuji Guowey Poultry Development Co, Ltd, Ltd.

1 Gujing Road, 311813, Wangjiajing, Zhuji, Zhejiang, China;

${ }^{3}$ Ukrainian Laboratory of Quality and Safety of Agricultural Products of National University of Life and Environmental Sciences of Ukraine,

Mashynobudivnykiv str., 7, 08162, Chabany, Kyiv region, Ukraine;

${ }^{4}$ National University of Life and Environmental Sciences of Ukraine, Heroiv Oborony St., 15, 03041 Kyiv, Ukraine;

${ }^{5}$ Institute of Animal Breeding and Genetics nd. a. M.V. Zubets of NAAS of Ukraine, Pohrebniaka Str. 1, 083213, Chubyns'ke, Kyivs'ka obl., Ukraine

parus_major@ukr.net

\begin{abstract}
Aim. To edit the duck genome by HDR-directed integration of the EGFP gene into the duck host genome in combination with SMGT using CRISPR/Cas9. Methods. HDR-mediated gene of green fluorescent protein (EGFP) was crried out by the combined action of four plasmids. The pX330 contained the Cas9 gene. Two plasmids contained sgRNA genes: pBR322-sgRNA1 and pBR322-sgRNA2. The pBR322-HDR-EGFP plasmid was constructed to contain the DNA vector with left homologous sequence part(LHP), the EGFP gene coding sequences and the right homologous sequence part(RHP). The DNA sequence data for designing the HDR-EGFPinsert and sgRNA 1 and sgRNA 2 were taken from the genome DNA sequence of Anas platyrhynchos Spindlin 1 (SPIN1) gene. Twenty four ducks (13 males and 11 females) of the Shaoxing breed were used for this experiment. The sperm transfection was performed using Lipofectamine 2000. Results. Thirty one ducks were obtained, 19 of which carried the EGFP gene. F2 analysis revealed that 16 ducks (F1) (14 females and 2 males) transmitted the transgene DNA to their offsprings. Thus $27.6 \%$ (56/203) of F2 descendants were positive for the transgene DNA construct. Conclusions. Exogenous DNA was successfully inserted into the duck genome.
\end{abstract}

Ke yw or d s: CRISPR/Cas9; EGFP; SMGT; Transgenic poultry; Duck

(C) 2019 O. Konoval et al.; Published by the Institute of Molecular Biology and Genetics, NAS of Ukraine on behalf of Biopolymers and Cell. This is an Open Access article distributed under the terms of the Creative Commons Attribution License (http://creativecommons.org/licenses/by/4.0/), which permits unrestricted reuse, distribution, and reproduction in any medium, provided the original work is properly cited 


\section{Introduction}

The bird has been used for a long time as a model of the embryonic development [1]. The bird egg is also a potential bioreactor for heterologous production of protein, especially for the production of recombinant therapeutic proteins in biopharmaceutical industry [2-5]. Birds have several advantages compared with other species: the short generation interval, high protein eggs, and good sperm production. Therefore, in the last 30 years there have appeared numerous studies focused on the transgenic poultry because it was expected to increase profitability and quality of commercial poultry stocks considerably [6].

The vast majority of studies on the transgenic poultry are focused on chickens (Gallus gallus) [4] and quails (Coturnix japonica) [7]. The eggs of duck (Anas platyrhynchos) are larger than the chicken and quail eggs [8], and have an advantage over the latter due to a possibility of usage as bioreactors. However, Anas platyrhynchos has not been studied thoroughly compared with other poultry, and there are no reported studies on a reliable genome engineering technique in the duck. Therefore, such work is of high significance for further use of ducks as a model of waterfowl species. It is necessary to pay a special attention to the egg-laying duck breeds characterized by a high level of egg productivity, rather than to the meat duck breeds.

The limiting factor of technologies of genetic engineering in case of poultry, especially waterfowl, is often a high cost of generating transgenic birds primarily due to the relatively low efficiency of transgenesis. The development of site-specific nuclease techniques, namely zinc finger nuclease (ZFN) [9], transcription activator-like effector nuclease (TALEN) [10], and clustered regularly interspaced short palindromic repeats (CRISPR)/ CRISPR-associated protein 9 (Cas9) provides a new solution of this problem $[11,12]$. CRISPR/Cas9 is easier in use, much cheaper and more efficient than ZNF and TALEN, thus it becomes a prevalent tool of molecular genetics and genetic engineering. CRISPR/Cas9 system uses a guide RNA to direct the Cas9 nuclease to the targeted DNA and produces double-strand-breaks (DSBs) [11]. The DSBs at the genomic locus of interest stimulate the genome DNA editing via non-homology-endjoining (NHEJ) or homology-directed repair (HDR). The number of studies on genome engineering of domestic animals, poultry and waterfowl with the CRISPR/Cas9 system is increasing. The CRISPR/Cas9 mediated genome engineering has been successfully used in chickens. However, there are no reports on applying this system in ducks.

Many techniques have been used to deliver transgenes into the poultry genome successfully, although their efficiency and reliability still pose a problem in poultry transgenesis. Nevertheless, several techniques made considerable progress. The techniques presently applied in poultry transgenesis include: retroviral infection of chicken embryos [13-15], in ovo electroporation of chicken embryos [16], microinjection of the liposome/foreign DNA complex into early stages of chicken embryos [17], and introduction of transfected primordial embryonic cells (PGCs) into the circulation for their re-colonization in gonad [4]. SMGT has also been successfully used to gen- 
erate transgenic chickens. Various combinations of methods of DNA binding to sperm were used to increase the effectiveness of exogenous DNA penetration into the oocyte during fertilization: incubation of native DNA with sperm $[2,18]$, with a liposome complex [18-24], with dimethylsulfoxide (DMSO) or with N,N-dimethylacetamide (DMAc) [2], electroporation [18], testis-mediated gene transfer (TMGT) using DNA/cationic polymer complex, transplanting of transfected spermatogonial stem cells (TTSSCs) using electroporation [25], spermatogonial stem cells (SSCs) with liposome/DNA complex [26], and SSCs incubation with DNA/cationic polymer complex to produce transgenic duck [25].

In this study, we used the CRISPR/Cas9 system to mediate the HDR directed EGFP gene integration into the duck's host genome combined with the SMGT.

\section{Materials and Methods}

Experimental animals: 24 Shaoxing ducks (13 males and 11 females) were selected for reproductive performance principle. The drakes aged ten months were selected with normal sperm of milky white or slightly yellowish, cream-looking texture, without flakes; concentration of $\geq 3 \times 10^{9}$ sperm cells per $1 \mathrm{ml}$; the activity of sperm $>70 \%$ (activity and motility of sperm cells were determined by the number of active sperm cells with rectilinear motion). The ducks aged ten months were selected for $\geq 90 \%$ egg production and fertility after artificial inseminations $\geq 90 \%$. The ducks were maintained in individual cages in the laboratory of the Zhuji Guowei Poultry Development Co, Ltd, P.R. China, which belongs to the Scientific Platform of
Institute of Animal Husbandry and Veterinary Science, Zhejiang Academy of Agricultural Sciences (Hangzhou, China). The protocol for animal use was approved by the Committee of bioethics of Institute of Animal Husbandry and Veterinary Science. All procedures with adult animals, ducklings and embryos were carried out according to the requirements of bioethics.

Collection and preparation of sperm for experimental transfection: The semen was taken from a drake by massaging the lumbar spine [27]. The sperm was collected into conical, polystyrene cups with the following dilution to 1:1 with the OPTI-MEM medium (Invitrogen, USA) and transportation to the laboratory (within 15-20 min after collection) for evaluation of quality and transfection. The sperm motility and concentration were evaluated with the standard procedure under the optical microscope.

Preparation of the DNA construct: The homology-directed repair (HDR)-mediated EGFP gene insertion was achieved by four plasmids. The pX330 plasmid, which contained Cas9 gene driven by a CMV promoter, was purchased at Addgene (http://www.addgene. org/42230/). Two sgRNA constructs were used to assist in generation of the DNA lesions at the proper genomic locus: pBR322-sgRNA1 and pBR322-sgRNA2. The expression of both sgRNAs was driven by the U6 promoters. The pBR322-HDR-EGFP plasmid was constructed to contain the left homologous sequence part, the EGFP gene coding sequences and the right homologous sequence part. The DNA sequence data for designing HDR-EGFP-insert and guide 20-nucleotide long parts of sgRNA 1 and sgRNA 2 were taken from the DNA sequense data of «Anas platyrhynchos Spindlin 1 
(SPIN1), mRNA» (NCBI Reference Sequence: XM_005016235.3). The EcoRI restriction site was inserted in the end of our HDR-EGFPinsert DNA to linearize the $\mathrm{pBR} 322$ vector with HDR-EGFP-insert DNA prior to [the] transfection process with EcoRI restriction enzyme.

Preparation of the mixture of DNAliposome complex with drake's semen cell for artificial insemination: to prepare the sperms for transfection procedure, $300 \mu \mathrm{l}$ of plasmid DNA ( $25 \mathrm{ng} / \mathrm{ml}$ of each vector) were mixed with $1 \mathrm{ml}$ of OPTI-MEM medium. Meanwhile, $300 \mu \mathrm{l}$ of Lipofectamine ${ }^{\circledR} 2000$ (Invitrogen, USA) were mixed with $1 \mathrm{ml}$ of OPTI-MEM medium. After the two solutions were incubated for $5 \mathrm{~min}$ at room temperature, they were combined and incubated at room temperature for another 20 minutes. Sperm fluid was centrifuged twice (1000 rpm, $10 \mathrm{~min}$ ), supernatant was removed, and the 1:1 dilution of precipitated sperm cells by the OPTI-MEM medium was made. The DNA-Lipofectamine ${ }^{\circledR} 2000$ complex was added to sperm cells after the second extraction and supernatant removal, then it was mixed and incubated at room temperature for an hour. After this preparation, the sperm motility was again evaluated to determine the sperm quality. The sperm cells prepared for transfection were used for deep artificial inseminations [28]. Five hundred million sperm cells were taken for one insemination. After insemination of ducks with the prepared for transfection sperm cells, the eggs were collected and incubated in the temperature regulated chamber for 10 or 28 days, afterwards the embryos were isolated or ducklings were grown.

Blood sampling, feather pulp and embryos: The feathers were plucked from each duck with blood in a pulp and put into individual tubes, then they were frozen at $-20{ }^{\circ} \mathrm{C}$ and stored until the DNA was extracted. Ducks' blood samples were collected from the Vena cutanea ulnaris, $2 \mathrm{ml}$ of blood were collected into the vacuum collection tube with EDTA. Genomic DNA was extracted from each blood sample. The embryos samples were collected from incubated eggs. $500 \mu \mathrm{l}$ of PBS solution were added, homogenized and pipetted to the isolated embryos, and then $100 \mu \mathrm{l}$ of homogenate were collected into individual tubes and frozen at $-20{ }^{\circ} \mathrm{C}$ until DNA was extracted.

Polymerase Chain Reaction: The existence of transgene DNA was verified by PCR method. Two primers located outside the EGFP gene were used: the forward primer ( 5 ) GTGTACGGTGGGAGGTC 3') and reverse primer (5 AAATGTGGTATGGCTGATTATG 3 ). The polymerase chain reaction program consisted of the initial step at $94^{\circ} \mathrm{C}$ for $3 \mathrm{~min}$, then the reaction was denatured at $94^{\circ} \mathrm{C}$ for $15 \mathrm{~s}$, and further annealed at $55^{\circ} \mathrm{C}$ for $15 \mathrm{~s}$ and elongated at $72^{\circ} \mathrm{C}$ for $30 \mathrm{~s}$ for 35 cycles. At the last stage the PCR product was elongated at $72^{\circ}$ for $3 \mathrm{~min}$. The generated PCR product was 903 bp in size and was sequenced to confirm the correct amplification. The PCR and sequencing experiments were carried out by Genery Biotechnology Company.

\section{Results}

As a result of the experiment we obtained $31 \mathrm{~F}_{1}$ birds (12 males and 19 females), 19 species of which had transgenic insertion, determined by PCR method (Figure 1) in: blood A63253, G60874, G61665; feathers - A63253; their embryos - 2617, A62783, G60874; ejaculate - A62783, 1221. Therefore the exogenous DNA insertion efficiency was $61.3 \%$ (19/31). 

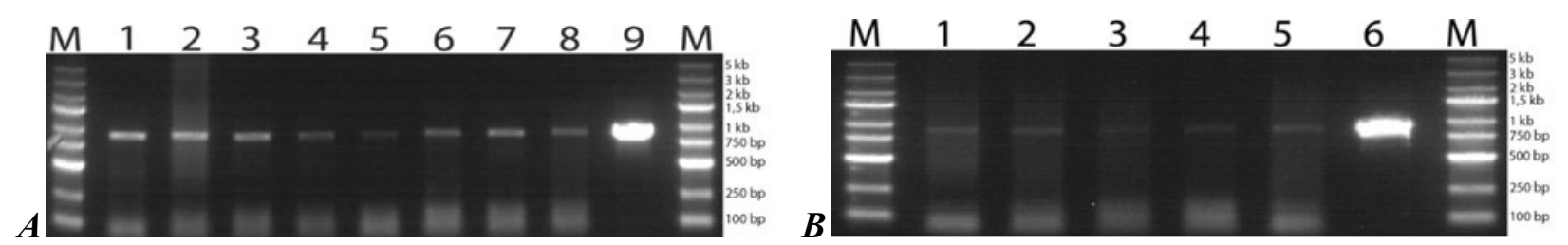

Fig. 1. Results of PCR detection of transgenic ducks generated with SMGT

The details of the samples (a): 1 and 8 - Embryos $\left(\mathrm{F}_{2}\right)$ from Father 2617; 2 - Embryo $\left(\mathrm{F}_{2}\right)$ from Father A62783; 3 Sperm $\left(\mathrm{F}_{1}\right)-2614 ; 4$ - Feathers $\left(\mathrm{F}_{1}\right)-\mathrm{G} 60168 ; 5-$ Feathers $\left(\mathrm{F}_{1}\right)-\mathrm{A} 63253 ; \mathbf{6}-\operatorname{Sperm}\left(\mathrm{F}_{1}\right)-1221 ; 7-\operatorname{Sperm}\left(\mathrm{F}_{1}\right)-$ A62783; 9 - Control. The details of the samples (b): 1, 2 and 3 - Embryos $\left(\mathrm{F}_{1}\right)$ - from Father 2617; 4 - Sperm $\left(\mathrm{F}_{0}\right)-$ 2612; 5 - Embryo $\left(\mathrm{F}_{1}\right)$ from Father A62783; 6 - Control. The $31 \mathrm{~F}_{1}$ ducks were mated with non-transgened ducks to obtain their $\mathrm{F}_{2}$ offsprings. One female and eight male founder birds did not produce any descendants. The offsprings' $\left(\mathrm{F}_{2}\right)$ analysis revealed that total 16 ducks $\left(\mathrm{F}_{1}\right)(14$ female and 2 male) transmitted the transgene to their offsprings. In total $\mathrm{F}_{2}$ ducks had 203 offsprings with 56 ducks (27.6\%) were positive for the EGFP gene. Moreover, two female and two male ducks with detected transgene DNA in the blood did not pass it on to their descendants; and 7 ducks with not detected transgene DNA in the blood, passed it on to their descendants.

Figures 2 and 3 show the variation of fertility level of females (F1) and transgene DNA transmission to descendants (F2) with respect to the day the eggs were laid and the descendants from F1 were born afterwards.

\section{Discussion}

During this study we used the sperm mediated gene transfer to generate transgenic ducks. The sperm cells were subsequently used to inseminate the female ducks. In 31 offsprings we obtained the following results: 19 ducks

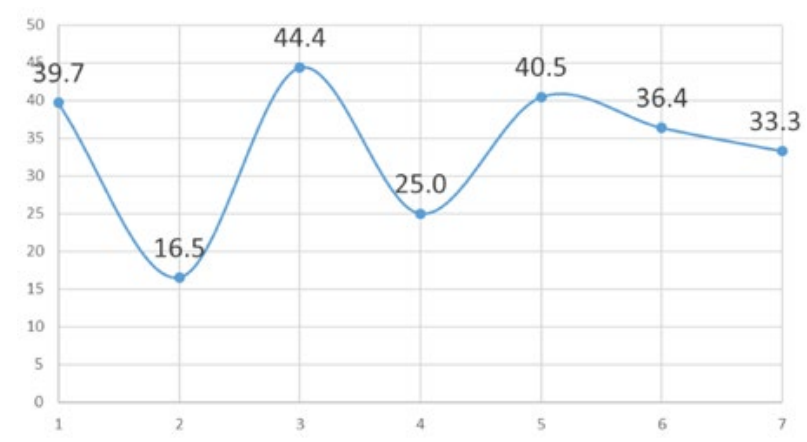

Fig. 2. Influence of the day of laying eggs (F1) on number of transgenic descendants (F2) (after SMGT), \% were positive for the EGFP transgene determined by PCR reaction. Although some $F_{1}$ birds were negative for the transgene in their blood, feather, and semen samples, the genome of their gametes could still contain the transgene, and the transgene was transmitted to their offsprings. The blood test showed the presence of the construct in 10 out of $19 \mathrm{fe}-$ males and in 9 out of 12 males. 14 out of 19 females produced a transgenic offspring, 2 out of 10 females with transgene in the blood did not produce a transgenic offspring. Thus, 17

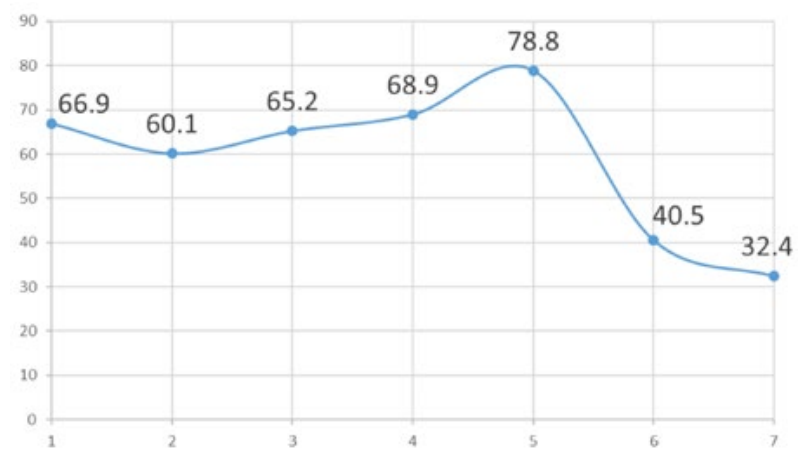

Fig. 3. Influence of the day of laying eggs (after transfection) (F1) on fertilizing ability of females. 
of 19 female birds were mosaic for transgene. The research on all animals' feathers as a result of transfection with sperm did not show the presence of transgenic constructs. Sperm analysis showed the presence of constructs in two drakes, which did not give an offspring, but had the transgenic construct found in the blood. 2 other males with no construct in the blood, also did not give a transgenic offspring. According to the results of the analysis of the offsprings, in 9 out of 12 males sperm and blood were transgenic. Only 4 out of 12 birds gave offsprings where 2 of them gave transgenic and 2 gave non transgenic offsprings. Only 1 out of 5 males with the construct found in the blood produced a transgenic offspring. Transgenic offsprings were obtained from one drake with no transgene in the blood. Thus, all transgenic males were mosaic. These results indicate that some of embryonic cells lost the modified genomic locus during the embryonic development, but it was apparently remained in a portion of sperm cells.

After the $F_{1}$ founder birds were obtained, they were crossed to produce $\mathrm{F}_{2}$ descendants. The results showed that $27.6 \%$ of $\mathrm{F}_{2}$ descendants were positive for the transgene construct. This result suggested that the transgene DNA was integrated into the host genome rather than in the episome. However, the transgene construct was transmitted primarily to daughters of the transgenic birds. $78.6 \%$ of $\mathrm{F}_{2}$ transgenic descendants were female. We pondered that the exogenous DNA fragment had been integrated into the $\mathrm{W}$ chromosome of female founders. This hypothesis can explain the fact that the female $\mathrm{F}_{1}$ founders primarily transmitted the transgene to their daughters. However it is still difficult to explain the fact that males also primarily transmitted the transgene to their daughters.

The table 1 shows the creation of transgenic poultry by transfection of sperm. The authors obtained successful results from the first generation embryo to the second generation of adult birds. The efficiency of transgene insertion ranged from $3.7 \%$ to $89.5 \%$.

Comparison of the effectiveness of the methods used for introduction of the transgene DNA construction suggests that liposomes provide the most successful results.

Up to date numerous cases of the CRISPR/ Cas9-genome-edited animals have been observed [29]. The fact of mosaicism while creating multicellular transgenic animals of different species was described by means of different vector systems for transgene delivery $[30,31]$. There were considered various factors which affect the level of mosaicism as a result of operations with the CRISPR/Cas9 [29]. The effect of concentration of the construct in embryos' survival and the success of editing the genome [32] were shown. The researches showed that an increase in concentration of the construct caused embryos' death [33]. It could be expected that after insemination with sperm, which contained lipofectamine and the construct, there will be a change in the time of success of the construction or insemination, because the complex of lipofectamine-spermatozoon-transgene was present in the female genital tract within 7 days. However in our studies we analyzed the survival of embryos after transfection and it should be noted that we found no connection between the day of egg laying and the embryo mortality at a certain period of its development or a level of mosaicism, neither between the presence of trans- 
genic constructs in different tissues. We also revealed no effect out of the presence of transgenic constructs in the blood during the transmission of transgenic constructs to descendants. It means that the presence of a transgenic construct in the blood neither leads to mandatory transmission of this construct to the descendants of a transgenic animal nor] affects the reproductive abilities of an animal in this case; we could not show an indirect connection between the level of mosaicism of the descendants received and the DNA degradation [33].
The mechanisms of DNA-mosaicism are associated with the lag of the genome editorial division from cell division $[34,35]$. The delay in the construction of the structure occurs due to involvement of the transcription system in its work at the stage of division of blastomeres.

DNA-mosaicism depends on 1) the species of organism in which the genome was edited; 2) targets in the genome; 3 ) the concentration of the transgene DNA; 4) the period of cell cycle during which the construction was introduced [29].

Table 1. Creation of transgenic poultry by transfection of sperm

\begin{tabular}{|c|c|c|c|c|c|c|}
\hline Species & Approach & Method & Plasmid & $\begin{array}{c}\text { Latest stage } \\
\text { transgenes } \\
\text { found }\end{array}$ & Results & Reference \\
\hline \begin{tabular}{l|} 
Chicken \\
(Gallus gallus)
\end{tabular} & \begin{tabular}{|l|} 
Liposome-like \\
Liposome
\end{tabular} & SMGT & $\mathrm{P}(\mathrm{CX}-\mathrm{EGFP})$ & F1 & $\begin{array}{l}9.5 \%(2 / 21)^{\mathrm{F} 1} \\
3.7 \%(2 / 53)^{\mathrm{F} 1} \\
\end{array}$ & 20 \\
\hline Chicken & Cationic polymer & TMGT & P(EGFP-N1) & F2 & \begin{tabular}{|l}
$56.5 \%(13 / 23)^{\mathrm{F} 1}$ \\
$50.0-66.7 \% \mathrm{~F}^{\mathrm{F} 1 \text { Embryo }}$ \\
$52.9 \%(9 / 17)^{\mathrm{F} 2}$ \\
$46.7-57.4 \%{ }^{\mathrm{F} 2}$ Embryo \\
\end{tabular} & \multirow[t]{3}{*}{25} \\
\hline Chicken & Electroporation & TTSSCs & P(EGFP-N1) & F1 & \begin{tabular}{|l|}
$11.1 \%(2 / 18)^{\mathrm{F} 1}$ \\
$12.5 \%(8 / 64)^{\mathrm{F} 1}$ Embryo \\
\end{tabular} & \\
\hline Duck & Cationic polymer & SSCs & P(EGFP-N1) & F1 & $54.8 \%(17 / 31)^{\mathrm{F} 1}$ & \\
\hline Chicken & Liposome & SMGT & $\mathrm{P}(\mathrm{eGFP})$ & F2 & $\begin{array}{l}89.5 \%(17 / 19)^{\mathrm{F} 1} \\
75 \%(6 / 8)^{\mathrm{F} 2}\end{array}$ & 21 \\
\hline Chicken & \begin{tabular}{|l|} 
DMSO \\
DMA \\
DNA incubation \\
\end{tabular} & SMGT & P(EGFP-N1) & F1 & $\begin{array}{l}38 \%(31 / 66)^{\mathrm{F} 1} \\
19 \%(5 / 23)^{\mathrm{F} 1} \\
5 \%(4 / 81)^{\mathrm{F} 1} \\
\end{array}$ & 2 \\
\hline Chicken & Liposome & SMGT & $\mathrm{P}(\mathrm{H} 2 \mathrm{~K}-\mathrm{S})$ & Embryo & $26.0 \%$ F1 Embryo & 19 \\
\hline Chicken & Liposome & SMGT & P(IRES EGFP2) & Embryo & $3.4 \%(1 / 29)^{\mathrm{F} 1 \text { Embryo }}$ & 22 \\
\hline Chicken & Liposome & SMGT & P(IRES EGFP2) & F2 & $\begin{array}{l}33.0 \%(2 / 6)^{\mathrm{F} 1} \\
33.0 \%(3 / 9)^{\mathrm{F} 1 \text { Embryo }} \\
37.5 \%(3 / 8)^{\mathrm{F} 2} \\
\end{array}$ & 24 \\
\hline Chicken & $\begin{array}{l}\text { DNAincubation } \\
\text { Electroporation } \\
\text { Liposome } \\
\end{array}$ & SMGT & $\begin{array}{l}\mathrm{P}(\text { (Bact-Luc-SV40poly-A } \\
\text { signal })\end{array}$ & Embryo & $\begin{array}{l}46.7 \%(14 / 30)^{\text {F1 Embryo }} \\
22.6 \%(7 / 31)^{\text {F1 Embryo }} \\
63.0 \%(34 / 54)^{\text {F1 Embryo }}\end{array}$ & 18 \\
\hline Chicken & Liposome & SSCs & pcDNA3.0(EGFP-MMx) & F1 & $10.5 \%(4 / 38)^{\mathrm{F} 1}$ & 26 \\
\hline Chicken & Liposome & SMGT & pUC18 & F1 & $\begin{array}{l}40 \%(4 / 10)^{\mathrm{F} 1} \\
50 \%(3 / 6)^{\mathrm{F} 1}\end{array}$ & 23 \\
\hline
\end{tabular}


It is possible that the editing process of the genome lags behind a rapid rate of the blastomeres formation in the early stages of development (blastula). Thus, only certain cells are the carriers of resulting mutations. In our studies we determined the efficiency of transgene DNA insertion by the presence of PCR product in DNA isolated from animals of the first generation (blood, sperm, feathers) and their offsprings (adults and embryos). Apparently, the analysis of our results indicates that all the animals we obtained were mosaic.

\section{Conclusion}

In this study we used CRISPR/Cas9 system combined with the sperm mediated gene transfer to introduce a transgenic DNA construct into the duck genome. $61.3 \%$ of the $F_{1}$ ducks were positive for the transgene in the experiment. The $\mathrm{F}_{1}$ ducks transmitted the gene to the next generation at a comparable transmission rate of $27.6 \%$. Therefore the exogenous DNA was successfully inserted into the duck genome. Meanwhile the transgene was transmitted primarily to the daughters of transgenic birds and as a result $78.6 \%$ of the transgenic $\mathrm{F}_{1}$ descendants were female.

\section{REFERENCES}

1. Davey $M G$, Tickle $C$. The chicken as a model for embryonic development. Cytogenet Genome Res. 2007;117(1-4):231-9.

2. Collares T, Campos VF, De Leon PM, Cavalcanti PV, Amaral MG, Dellagostin OA, Deschamps JC, Seixas $F K$. Transgene transmission in chickens by sperm-mediated gene transfer after seminal plasma removal and exogenous DNA treated with dimethylsulfoxide or N,N-dimethylacetamide. J Biosci. 2011;36(4):613-20.
3. Lillico $S G$, Sherman A, McGrew MJ, Robertson $C D$, Smith J, Haslam C, Barnard P, Radcliffe PA, Mitrophanous KA, Elliot EA, Sang HM. Oviduct-specific expression of two therapeutic proteins in transgenic hens. Proc Natl Acad Sci U S A. 2007;104(6):1771-6.

4. Han JY. Germ cells and transgenesis in chickens. Comp Immunol Microbiol Infect Dis. 2009;32(2):61-80.

5. Kwon MS, Koo BC, Kim D, Nam YH, Cui XS, Kim NH, Kim T. Generation of transgenic chickens expressing the human erythropoietin (hEPO) gene in an oviduct-specific manner: Production of transgenic chicken eggs containing human erythropoietin in egg whites. PLoS One. 2018;13(5):e0194721.

6. Woodcock ME, Idoko-Akoh A, and McGrew MJ. Gene editing in birds takes flight. Mamm Genome, 2017; 28(7-8): 315-23.

7. Mizuarai S, Ono K, Yamaguchi K, Nishijima K, Kamihira M, Iijima $S$. Production of transgenic quails with high frequency of germ-line transmission using VSV-G pseudotyped retroviral vector. Biochem Biophys Res Commun. 2001;286(3):456-63.

8. Arthur J. Egg Innovations and Strategies for Improvements, Academic Pres (an imprint of Evsevier), 2017. $607 p$.

9. Kim YG, Cha J, Chandrasegaran S. Hybrid restriction enzymes: zinc finger fusions to Fok I cleavage domain. Proc Natl Acad Sci U S A. 1996;93(3):1156-60.

10. Bedell VM, Wang Y, Campbell JM, Poshusta TL, Starker CG, Krug RG 2nd, Tan W, Penheiter SG, Ma AC, Leung AY, Fahrenkrug SC, Carlson DF, Voytas DF, Clark KJ, Essner JJ, Ekker SC. In vivo genome editing using a high-efficiency TALEN system. Nature. 2012;491(7422):114-8.

11. Cong L, Ran FA, Cox D, Lin S, Barretto R, Habib N, Hsu PD, Wu X, Jiang $W$, Marraffini LA, Zhang $F$. Multiplex genome engineering using CRISPR/Cas systems. Science. 2013;339(6121):819-23.

12. Dimitrov L, Pedersen D, Ching KH, Yi H, Collarini EJ, Izquierdo $S$, van de Lavoir MC, Leighton PA. Germline Gene Editing in Chickens by Efficient CRISPR-Mediated Homologous Recombination in Primordial Germ Cells. PLoS One. 2016;11(4):e0154303.

13. Salter DW, Smith EJ, Hughes SH, Wright SE, Fadly $A M$, Witter RL, Crittenden $L B$. Gene insertion 
into the chicken germ line by retroviruses. Poult Sci. 1986;65(8):1445-58.

14. Thoraval P, Afanassieff $M$, Cosset FL, Lasserre F, Verdier G, Coudert F, Dambrine G. Germline transmission of exogenous genes in chickens using helperfree ecotropic avian leukosis virus-based vectors. Transgenic Res. 1995;4(6):369-77.

15. Iba $H$. Gene transfer into chicken embryos by retrovirus vectors. Dev Growth Differ. 2000;42(3):213-8.

16. Nakamura H, Funahashi J. Introduction of DNA into chick embryos by in ovo electroporation. $\mathrm{Me}$ thods. 2001;24(1):43-8.

17. Longmuir KJ, Haynes SM, Dickinson ME, Murphy JC, Willson RC, Waring AJ. Optimization of a peptide/non-cationic lipid gene delivery system for effective microinjection into chicken embryo in vivo. Mol Ther. 2001;4(1):66-74.

18. Nakanishi A, Iritani A. Gene transfer in the chicken by sperm-mediated methods. Mol Reprod Dev. 1993;36(2):258-61.

19. Rottmann OJ, Antes R, Höfer P, Maierhofer G. Liposome mediated gene transfer via spermatozoa into avian egg cells. J Anim Breed Genet. 1992; 109(16): 64-70.

20. Yang CC, Chang HS, Lin C-J, Hsu CC, Cheung JI, Hwu L, Cheng Winston. Cock spermatozoa serve as the gene vector for generation of transgenic chicken (Gallus gallus). Asian-Australas J Anim Sci. 2004; 17: 885-91.

21. Harel-Markowitz E, Gurevich M, Shore LS, Katz A, Stram Y, Shemesh M. Use of sperm plasmid DNA lipofection combined with REMI (restriction enzyme-mediated insertion) for production of transgenic chickens expressing eGFP (enhanced green fluorescent protein) or human follicle-stimulating hormone. Biol Reprod. 2009;80(5):1046-52.

22. Samoilov A, Martirosian V, Baryshnikov A, Surayeva $N$. The usage linker of based chicken spermmediated gene transfer for development and study of methods of therapeutic proteins production. Ross Bioterapevt Z. 2011; 11(3): 53-6.

23. El-Gendy EA, Ahmed MM, El-Tantawy SM. Development of transgenic chickens by sperm-mediated gene transfer. Afr J Biotechnol. 2013; 12: 27552763.
24. Samoylov AV, Kesyan AZ, Suraeva NM. Development of transgenic chicken with a gene of human granulocyte colony-stimulating factor using spermmediated gene transfer. Biology Bulletin. 2013; 40(5): 419-22. doi:10.1134/s1062359013040134

25. Li B, Sun G, Sun H, Xu Q, Gao B, Zhou G, Zhao W, $W u X$, Bao $W$, Yu F, Wang $K$, Chen $G$. Efficient generation of transgenic chickens using the spermatogonial stem cells in vivo and ex vivo transfection. Sci China C Life Sci. 2008;51(8): 734-42.

26. Min S, Qing S, Hui Y, Zhi FD, Rong QY, Feng X, Chun BL Generation of antiviral transgenic chicken using spermatogonial stem cell transfected in vivo. Afr J Biotechnol. 2012; 11(6): 1509-15.

27. Watanabe $M$, Sugimori $Y$. Studies on the artificial insemination in ducks. Zootecnica e Veterinaria, Anno XII. 1957; 3: 119-24.

28. Onishi N, Kato Y, Futamura K. Studies on the artificial insemination in ducks. Bull Nat Inst Agric Sci, Series G. 1955; 11: 2-16.

29. Mehravar M, Shirazi A, Nazari M, Banan M. Mosaicism in CRISPR/Cas9-mediated genome editing. Dev Biol. 2019;445(2):156-162.

30. Zhang Z, Sun P, Yu F, Yan L, Yuan F, Zhang $W$, Wang T, Wan Z, Shao $Q$, Li Z. Transgenic quail production by microinjection of lentiviral vector into the early embryo blood vessels. PLoS One. 2012;7(12):e50817.

31. Scott BB, Lois C. Generation of tissue-specific transgenic birds with lentiviral vectors. Proc Natl Acad Sci U S A. 2005;102(45):16443-7.

32. Midic $U$, Hung $P H$, Vincent $K A$, Goheen $B$, Schupp $P G$, Chen DD, Bauer DE, VandeVoort CA, Latham $K E$. Quantitative assessment of timing, efficiency, specificity and genetic mosaicism of CRISPR/Cas9-mediated gene editing of hemoglobin beta gene in rhesus monkey embryos. Hum Mol Genet. 2017;26(14):2678-2689.

33. Tu Z, Yang $W$, Yan S, Yin A, Gao J, Liu X, Zheng Y, Zheng J, Li Z, Yang S, Li S, Guo X, Li XJ. Promoting Cas9 degradation reduces mosaic mutations in nonhuman primate embryos. Sci Rep. 2017;7:42081.

34. Niu Y, Shen B, Cui Y, Chen Y, Wang J, Wang L, Kang Y, Zhao X, Si W, Li W, Xiang AP, Zhou J, Guo X, Bi Y, Si C, Hu B, Dong G, Wang H, Zhou Z, 
Li T, Tan T, Pu X, Wang F, Ji S, Zhou Q, Huang X, Ji $W$, Sha J. Generation of gene-modified cynomolgus monkey via Cas9/RNA-mediated gene targeting in one-cell embryos. Cell. 2014;156(4):836-43.

35. Chen $Y$, Zheng $Y$, Kang $Y$, Yang $W$, Niu Y, Guo X, Tu Z, Si C, Wang H, Xing R, Pu X, Yang SH, Li S, Ji W, Li XJ. Functional disruption of the dystrophin gene in rhesus monkey using CRISPR/Cas9. Hum Mol Genet. 2015;24(13):3764-74.

\section{Генерація трансгенних уток шляхом CRISPR /} CAS9-опосередкованої вставки генов в посднанні $з$ сперматозоїд-опосередкованим перенесення генів (SMGT)

О. Коновал, П. Король, П. Табака, С. Костенко, Л. Лу, А. Чепіга, М. Дорошенко, М. Драгулян, Х. Бу, Ц. Хуанг, Л. Лі

Мета. Редагувати геном качки методом HDRспрямованої інтеграції гена EGFP в геном господаря в поєднанні з SMGT з використанням CRISPR / Cas9. Методи. Вставка HDR-опосередкованого гена зеленого флуоресцентного білка (EGFP) була досягнута спільною дією чотирьох плазмід. Перша плазміда рX330 містила ген Cas9. Ще дві плазміди містили спейсери sgRNA: pBR322-sgRNA1 i pBR322-sgRNA2. Четверта плазміда pBR322-HDR-EGFP була сконструйована так, щоб вона містила вектор ДНК з лівою частиною гомологічної послідовності (LHP), кодуючою послідовністю гена EGFP і правою частиною гомологічної послідовності (RHP). Для конструювання HDR-EGFPвставки і 20-нуклеотидних направляючих sgRNA 1 i sgRNA 2 дані були взяті з даних послідовності геному «Anas platyrhynchos Spindlin 1 (SPIN1)» в базі NCBI. Для цього експерименту було використано 24 качки (13 самців і 11 самок) породи Шаосін. Трансфекцію сперматозоїдів здійснювали з використанням реагенту Lipofectamine 2000. Результати. Було отримано 31 качку, з яких 19 містили ДНК-трансгенну вставку, яка була визначена методом ПЛР. Аналіз потомства (F2) показав, що всього 16 качок (F1) (14 самок і 2 самці) передали трансгенну ДНК своїм потомкам. Результати показали, що 27,6 \% (56/203) нащадків F2 були позитивними щодо конструкції трансгенної ДНК. Висновки. Результати свідчать, що екзогенна ДНК була успішно вставлена в геном качки.
Ключов і с слов а: CRISPR / Cas9; EGFP; SMGT; Трансгенний птах; качка

\section{Генерация трансгенных уток путем CRISPR / CAS9-опосредованной вставки генов в сочетании со сперматозоид-опосредованным переносом генов (SMGT)}

О. Коновал, П. Король, П. Табака, С. Костенко, Л. Лу, А. Чепига, М. Дорошенко, М. Драгулян, Х. Бу, Ц. Хуанг, Л. Ли

Цель. Редактировать геном утки методом HDR -направленной интеграции гена EGFP в геном хозяина в сочетании с SMGT с использованием CRISPR/Cas9. Методы. Внедрение HDR-опосредованного гена зеленого флуоресцентного белка (EGFP) было достигнуто совместным действием четырех плазмид. Первая плазмида pX330 содержала ген Cas9. Еще две плазмиды содержали спейсеры sgRNA: pBR322-sgRNA1 и pBR322-sgRNA2. Четвертая плазмида pBR322-HDREGFP была сконструирована так, чтобы она содержала вектор ДНК с левой частью гомологичной последовательности (LHP), кодирующей последовательностью гена EGFP и правой частью гомологичной последовательности (RHP). Для конструирования HDR-EGFPвставки и 20-нуклеотидных направляющих $\operatorname{sgRNA} 1$ и sgRNA 2 данные были взяты из последовательности ДНК генома утки «Anas platyrhynchos Spindlin 1 (SPIN1)» в базе NCBI. Для этого эксперимента было использовано 24 утки (13 самцов и 11 самок) породы Шаосин. Трансфекцию сперматозоидов осуществляли с использованием реагента Lipofectamine 2000. Результаты. Было получено 31 утку, из которых 19 имели в геноме трансгенную ДНК (EGFP), которая была определена методом ПЦР. Анализ потомков (F2) показал, что всего 16 уток (F1) (14 самок и 2 самцов) передали трансгенную ДНК своим потомкам. Результаты показали, что 27,6 \% (56/203) потомков F2 были позитивными в отношении конструкции трансгенной ДНК. Выводы. Результаты свидетельствуют, что экзогенная ДНК была успешно вставлена в геном утки.

Ключевые слова: CRISPR/Cas9, EGFP, SMGT, Трансгенная птица, Утка 